\title{
Pasar Bebas Menuju Indonesia Berkemajuan
}

\author{
Nur Amalia \\ Jurusan Perbankan Syariah Fakultas Ekonomi Dan Bisnis Islam \\ Nuramaliaa@Gmail.Com
}

\begin{abstract}
Abstrak
Idealisme perdagangan bebas tidak lepas dari pemikiran ekonom klasik bahwa implementasi aktivitas perdagangan internasional tanpa hambatan tarif maupun nontarif akan meningkatkan kesejahteraan masyarakat dunia. Namun realita menunjukkan hal sebaliknya, dimana kesejahteraan yang diraih masyarakat dunia sangat tidak merata. Kesenjangan di antara dua kelompok ini semakin lebar ketika dunia memasuki era liberalisasi perdagangan. Fenomena ini menarik untuk dikaji, mengapa ada gap antara idealisme dan realitas. Idealisme perdagangan bebas yang dibangun oleh ekonom klasik bersandar pada asumsi yang secara utuh tidak sesuai kenyataan, diantaranya bahwa setiap negara yang akan berdagang memiliki kapasitas ekonomi yang sama. Sekalipun WTO sebagai lembaga perdagangan dunia mengakomodir fenomena ini dalam pasal-pasalnya, namun dalam kenyataannya sulit terlaksana secara optimal. Egoisme negara maju yang dibentuk oleh prinsip ekonomi konvensional sering mengemuka melalui argumen yang bernuansa politis. Sementara negara-negara berkembang memiliki kelemahan yang mencakup aspek ekonomi, sosial, dan kelembagaan sehingga tidak memiliki posisi tawar dalam percaturan ekonomi global. Islam menawarkan prinsip bahwa perdagangan bebas adalah perdagangan yang mencoba mengoptimalkan hubungan perdagangan dengan luar negeri di satu sisi dan melarang perdagangan komoditas tertentu yang mengganggu kemaslahatan kaum muslimin di sisi lain. Islam pun berpandangan bahwa asas perdagangan bebas bukan terletak di komoditi namun di pelakunya (pedagang). Dengan demikian pemerintah negara yang bersangkutan seharusnya memiliki sikap yang jelas dan tegas dalam menjalani perdagangan bebas yang berorientasi untuk kesejahteraan masyarakatnya.
\end{abstract}

Kata kunci : Perdagangan Bebas; Pemerataan; Pandangan Islam 


\section{Pengertian pasar bebas}

Perdagangan antarnegara seperti ekspor dan impor, regulasinya diatur oleh negara yang bersangkutan. Hakikat dari pasar bebas adalah salah satu bentuk perjanjian perdagangan anatar dua negara atau lebih. Dilansir dari Britannica Encyclopedia (2015), pasar bebas yaitu sistem pertukaran ekonomi yang pajak, kendali mutu, kuota, tarif, serta bentuk lain intervensi ekonomi terpusat oleh pemerintah bersifat minimal bahkan tidak ada. Sehingga dapat disimpulkan bahwa pasar bebas merupakan perdagangan yang tidak diatur oleh otoritas yang memaksa seperti pemerintah. Dalam pasar bebas, pajak serta bea cukai barang yang masuk atau keluar dari suatu negara biasanya akan dihapuskan. 


\section{Pengertian pasar bebas menurut para ahli}

Adam smith, yang sering dijuluki sebagai bapak ekonomi mengatakan bahwa pasar bebas sudah memberikan kebebasan pada masyarakat luas untuk bisa membuat dan melakukan kegiatan jual beli barang sesuka hati mereka.

Selain itu, pasar bebas pun mampu membuka pasar hingga keluar negeri dan melahirkan persaingan ekonomi yang lebih luas yang mana setiap orang secara alami tentu akan lebih memilih barang dengan harga yang murah demi memperkaya dirinya sendiri tanpa adanya campur tangan pemerintah.

Disisi lain, David Ricardo menjelaskan bahwa pasar bebas adalah suatu kegiatan perdagangan luar negeri yang melibatkan lebih dari dua negara yang masing-masing diantaranya akan melakukan perdagangan tanpa ada masalah dari pihak pemerintah.

Artinya, setiap masyarakat memiliki kebebasan dalam melakukan perdagangan antar negara tanpa hambatan dari pihak pemerintahannya masing-masing.

Berdasarkan penjelasan dari para ahli diatas, bisa kita tarik kesimpulan bahwa pasar bebas memiliki hubungan yang erat dengan kebijakan pemerintah tentang suatu perdagangan. Artinya, pemerintah tidak akan melakukan tindakan diskriminatif atau menghambat proses perdagangan, terutama kegiatan impor dan ekspor barang. (mahmud, 2015) 


\section{Tujuan pasar bebas}

a) Membuka peluang ekonomi

Pasar bebas dapat membuka peluang ekonomi dengan cara memperluas pasar. Produk yang awalnya diproduksi untuk dijual di dalam negeri, dapat dijual ke luar negeri dengan mudah. Tidak adanya pajak membuat pasar menjadi lebih luas karena tidak dibatasi oleh pajak antarnegara yang mahal. Terbukanya pasar membuat produsen dalam negeri dapat mengekspor barang dalam jumlah besar namun biaya ekspor yang rendah. Hal ini membuat negara memiliki komoditas ekspor unggulannya yang dapat meningkatkan perekonomian.

b). Meningkatkan perekonomian

Diselenggarakannya pasar bebas bertujuan meningkatkan pendapatan negara juga perekonomian penduduknya. Pasar yang luas memberikan permintaan produk yang lebih besar bagi produsen dalam negeri. Semakin banyak permintaan pasar, maka akan semakin besar pula peningkatan ekonomi yang terjadi. Selain itu, terbukanya pasar yang luas mengundang datangnya para investor asing untuk mendirikan bisnis di dalam negeri. Pembukaan usaha baru maupun pengembangan usaha menjadi lebih besar dapat memberikan 
lapangan pekerjaan. Hal ini dapat mengurangi adanya pengangguran serta meningkatkan pendapatan per kapita masyarakat. (Nainggolan, 2018)

c). Meningkatkan teknologi

Pasar bebas memungkinkan teknologi yang lebih maju dari luar negeri untuk masuk dengan mudah ke dalam negeri. Dengan adanya pasar bebas, peningkatan teknologi bisa dilakukan dengan mudah dan merata. Selain meningkatkan teknologi, persaingan ketat pasar bebas juga menuntut peningkatan sumber daya manusia suatu negara.

d). Memenuhi kebutuhan dalam negeri

Pasar bebas membantu pemerintah untuk memenuhi kebutuhan dalam negeri. Tidak semua barang dapat diproduksi di dalam negeri, sebagian barang harus diimpor untuk dapat memenuhi kebutuhan. Tidak adanya biaya impor dan persaingan ketat akibat pasar bebas membuat pemerintah dapat memenuhi kebutuhan dalam negeri dengan harga yang lebih murah. (riyanti, 2016) 


\section{Pandangan islam terhadap konsep pasar bebas}

Prinsip kebebasan pasar yang ditawarkan Smith pada intinya adalah kebebasan alami dalam ekonomi dan keadilan, Smith membangun prinsip kebebasan berdasarkan pemahamannya tentang hak-hak asasi manusia secara alami (kodrati) yang kemudian dianggap sebagai hak-hak suci, suci dalam arti tidak boleh dilanggar. Sedangkan kebebasan merupakan salah satu dari hakhak asasi manusia, oleh karena itu hak-hak asasi ini secara otomatis disucikan. Pemahaman ini oleh Adam Smith dijadikan dasar berfikir logis dan dituangkan dalam sebuah sistem ekonomi yang kemudian dikenal dengan istilah pasar bebas. Walaupun demikian, sistem pasar bebas ini gagal menangkis serangan-serangan kelompok sosialis yang menuduhnya sekedar 6M. Umer Chapra, Islam Dan Tantangan Ekonomi, Islamisasi Ekonomi Kontemporer, alih bahasa Nur Hadi Ihsan dan Rifqi Amar, cet. I (Surabaya: Risalah Gusti dan IIIT-Malaysia 1999), h. 19. 7Adam Smith, An Inquiry Into The Nature And Causes Of The Wealth Of Nations, (Newyork: The Modern Library, 1937), h. 651. 4 menanggapi sinyal-sinyal harga dan menguntungkan pemilik alat-alat produksi, yaitu kapitalis, untuk mengambil keputusankeputusan yang merugikan kepentingan kelompok pekerja, atau proletariat jadi kapitalis, dalam rangka memenuhi kepentingannya sendiri, menekan 
ongkos sampai ke tingkat yang berlaku, dan dalam rangka mengatasi tingkat keuntungan yang senantiasa menurun, memusatkan kekayaan di tangan segelintir orang saja. Kontradiksi-kontradiksi internal diantara kepentingankepentingan berbagai kelas menjurus kepada revolusi poletar dan kediktatoran. (hazbalah, 2017) 


\section{KELEBIHAN DAN KEKURANGAN PASAR BEBAS}

\section{Kelebihan Pasar Bebas}

- Semua orang bebas untuk memiliki kekayaan serta sumber daya produksi

- Masyarakat bisa mengembangkan kreatifitas dan inovasi

- Persaingan antar produsen menciptakan motivasi tinggi untuk menciptakan produk yang berkualitas

- Kegiatan yang dijalani berdasarkan prinsip ekonomi, sehingga efisien dan efektif.

\section{Kekurangan Pasar Bebas}

- Terjadi eksploitasi terhadap masyarakat berekonomi lemah yang dilakukan oleh para penguasa yang memiliki ekonomi kuat.

- Terjadinya monopoli yang bisa berujung pada kerugian terhadap masyarakat

- Kesenjangan ekonomi yang signifikan antara golongan ekonomi yang kuat dan lemah

- Perekonomian cenderung tidak stabil sehingga menimbulkan masalah dalam pasar. (wilyono, 2019) 


\section{Fungsi pasar bebas}

Pasar bebas memiliki fungsi didalam perekonomian negara diantara nya akan dibahas dibawah ini.

1. Pasar bebas bisa memberikan informasi dan juga lebih tepat tentang harga dan juga jumlah permintaan barang.

2. Pasar bebas dapat memberikan perangsang pada para pengusaha agar dapat mengembangkan usaha mereka.

3. Pasar bebas juga dapat memberikan perangsang pada para pengusaha agar dapat memperoleh keahlian yang modern.

4. Pasar bebas juga dapat memberikan dan juga merangsang penggunaan barang dan juga factor produksi dengan cara yang lebih efisien.

5. Pasar bebas dapat memberikan kebebasan dengan sepenuhnya pada masyarakat agar dapat melakukan kegiatan ekonomi. (marzuki, 2018) 


\section{DAFTAR PUSTAKA}

hazbalah, m. (2017). islam dan pasar bebas. jurnal ekonomi islam, 4(3), 11-32.

mahmud, s. (2015). konsep pasar bebas. jurnal ekonomi, 5(2), 33-54.

marzuki. (2018). pasar bebas dan kelebihannya. jurnal ekonomi, 5(3), 34-54.

riyanti, t. (2016). pasar bebas dan kebermanfaatannya. jurnal ekonomi, 4(2), 34-76.

slamet. (2017). kepemimpinan pasar bebas. jurnal ekonomi, 6(4), 34-45.

wilyono. (2019). ruang lingkup pasar bebas. jurnal ekonomi, 2(1), 56-65. 